\title{
REAL ESTATE VALUATION IN URBAN REGENERATION APPLICATION; CASE STUDY OF KONYA
}

\author{
1Sukran YALPIR, 2Eda BAYRAK \\ 1,2 Selcuk University, Department of Geomatics Engineering, Campus, Selcuklu, Konya, TURKEY \\ sarici@selcuk.edu.tr, 2edabayrak006@hotmail.com
}

(Geliş/Received: 07.11.2016; Kabul/Accepted in Revised Form: 29.01.2017)

\begin{abstract}
The land valuation is a field that must be done with scientific, right and independent perspective. The land valuation is not only in the estimation of marketing value, additionally it finds usage areas like mortgaged sales, expropriation, urban renew al etc.

This study is about the expropriation and how the land valuation must be done in this area. In this study, the application area was chosen as the premises of the expropr iation in the district of Uluirmak in Meram, KONYA, and the valuation before the application was done with the Cobb- Douglas Hybrid regression method. Twenty three criterion's that belong to the number of 1078 constructed and unconstructed premises were utilized. In consequence of the nonlinear regression modeling it succeeded about $98 \%$. The land valuation does not only depend on the area index, it can be done in a short time while a lot of criterion's are considered, by this way the proprietors are able to get their rights with this developed mathematical model.
\end{abstract}

Key Words: Real estate valuation, Urban regeneration, Regression, Cobb-Douglas.

\section{Kentsel Dönüşüm Uygulamalarında Taşınmaz Değerleme; Konya Örneği}

ÖZ: Taşınmaz değerlemesi bilimsel, doğru ve bağımsız olarak yapılması gereken bir alandır. Taşınmaz değerleme sadece piyasa değerini tahmin etmede değil ipotekli satışlarda, kamulaştırmada, imar uygulamalarında, kentsel dönüşüm ve birçok konuda kullanım alanı bulunmaktadır.

Bu çalışmada, kentsel dönüşüm ve kentsel dönüşüm alanında yapılan taşınmaz değerlemenin nasıl olması gerektiği konusundadır. Çalışmada uygulama alanı olarak seçilen Konya ili Meram ilçesinde bulunan Uluırmak mahallesindeki kentsel dönüşüm uygulamasındaki taşınmazların, uygulama öncesi değerlemesi Cobb Douglass hibrit regresyon yöntemi ile yapılmıştır. Çalışma alanında 1078 adet yapılı ve yapısız taşınmaza ait 23 kriter kullanılmıştır. 23 kriterin 17 tanesi arsaya 6 tanesi yapıya ait özellikleri içermektedir. Nonlineer regresyon modellemesi sonucunda yaklaşık \%98 başarı elde edilmiştir. Taşınmazların, sadece taşınmaz alan endeksli değil çok sayıda kriter göz önünde bulundurarak kısa sürede yapılabileceği ve mülk sahiplerinin haklarının eşit olarak verilebileceği geliştirilen matematiksel model ile ortaya konmaya çalışılmıştır.

Anahtar Kelimeler: Taşımaz değerleme, Kentsel dönüşüm, Regresyon, Cobb-Douglas

Note: This paper has been presented at the Selcuk International Scientific Conference on Applied Sciences (ISCAS 2016) held in Antalya (Turkey), September 27-30, 2016.

DOI: 10.15317/Scitech.2017.73 


\section{INTRODUCTION}

Urban renewal involves a partial or total renewal of a city through suitable projects and strategic plans that provide options for solving urban problems and seek for permanent solutions for physical, social and environmental problems in a specific area. Urban renewal aims to create sustainable, habitable, healthy and contemporary cities (Ucar, 2009). Urban renew al works involve highly critical phases such as identification of the renewal site appraisal of the value of a real estate based on its prior and subsequent condition. In order to avoid doing injustice to the property owners, it is essential that the real estates be appraised as per their original and new conditions. Today, this is done by municipalities based on their own arrangements. Previous urban renewal works mostly involved comparative appraisal efforts based on the locations of the real estates. Today, the significance of this particular aspect has come to be appreciated and the municipalities spend more efforts for bringing about arrangements to tackle this complicated issue.

The determination of real-estate value is today's one of the most popular labor branch. The factors like the difficulty in finding real-estate similar to the considered estate, having many factors affecting the value, variability due to local regions and preferences and the difficulty in defining the situation with common mathematical equations necessitate the new searches for the determination of values. Nowadays, reconstruction and urban renewal works require fair, accurate and quick real estate valuation just as the case in the more commonly known practices such as sale, purchase, taxation and expropriation. Owing to the fact that there are vast number of factors that determine the value of the real estates and that mass appraisal have to be valued all at the same time, traditional valuation methods may not be fit to be applied in the case of such applications. For this reason, a mathematical model should be developed to be used in the valuation of mass appraisal.

Multiple regression analysis that is frequently found in the literature is regarded as a valid and widely accepted method (Yalpir et al., 2002; Rossini, 1998; Stephen et al., 2010). It is calculated based on purchase and sale values and involves a number of real estate values, the accuracy of the method is further improved. Despite practical hardships, it is nevertheless a preferable method in terms of its close approximation to the purchase and sale values. Regression analysis for real estates_can be described as a statistical technique that allows a real estate to be evaluated with the relevant characteristics in order to identify the significant determinants of the real estate value and the numbers thereof.

In the absence of linearity between independent variables and dependent variables, nonlinea $\mathrm{r}$ regression method -being a stochastic method- can be applied. In the multiple regression model, there is a number of independent variables that affect the dependent variable and the general purpose for such studies is twofold:

1. Find out which independent variable/variables affect the dependent variable the most.

2. Estimate the value of the dependent variable through the variables that are known to affect the dependent variable. The purpose of the study may be to find one or both of them (Alpar, 1997).

With respect to the both purposes, regression method can be regarded as the right method for real estate valuation. However, due to the fact that there is a wide variety of real estate available, the method is required to be modeled separately based on the type of the property. Whereas, valuation of both land and buildings can be performed at the same time through Cobb-Douglas hybrid modeling without necessarily relying on separate modeling for property type (Ozkan and Yalpir., 2005).

The implementation area for this study is Uluirmak District in Meram county, Konya province, which is one of the urban renew al areas. This study employs a regression analysis called Cobb-Douglas Hybrid method instead of traditional methods. A data set, consisting of 23 criteria, -17 for land, 6 for buildings- was established for the study area, which is composed of 1078 real estates with and without buildings on them, and the values obtained through the model thus established were compared with the existing values. 


\section{REGRESSION ANALYSIS}

Regression analysis involves expressing the relationship between a variable with one or more than variable through a mathematical function. Depending on the type of mathematical functions it is divided into two methods, namely:

- Linear regression method

- Non linear regression method (Orhunbilge, 2002).

While linear models are estimated to be impartial, normally distributed and with minimum variance, non linear regression models mostly apply when the sample size is fairly big (Kutner et al., 1996).

Linear regression studies can be commonly encountered in most real estate valuation studies in the literature (Din, et al., 2001; Isakson, 2001). It is well known that there are many factors affecting the valuation of real-estates each of which has different effect on the value. The value estimation considering many criteria can be made with multi-regression methods. In the real estate market, the values pertaining to the items being sold and purchased (dependent variables) and the criteria that affect the property value (independent variables) are summed up and subjected to a mathematical model that is capable of making value estimations using multiple regression method.

In the linear regression model, the dependent variable is assumed to be a linear function of one or more independent variables plus an error introduced to account for all other factors (Equation 1):

$$
y_{i}=\beta_{0}+\beta_{1} x_{i 1}+\beta_{2} x_{i 2} \ldots \ldots . \beta_{k} x_{i k}+u_{i}
$$

In the above regression equation,

$\mathrm{y}_{\mathrm{i}}$ : the dependent variable, (the value of the real-estate),

$\mathrm{X}_{\mathrm{i} 1}, \ldots . ., \mathrm{X}_{\mathrm{iK}}$ : the independent or explanatory variables, (number of room, age, etc.) and

$\mathrm{u}_{\mathrm{i}}$ : the disturbance or error term. The goal of the regression analysis is to obtain the estimations of the unknown parameters.

$\beta_{1}, \ldots, \beta_{\mathrm{k}}$ indicates how a change in one of the independent variables affects the values taken by the dependent variable.

Non linear regression models can also be demonstrated in a simple form like linear models (Equation 2):

$$
y_{i}=f\left(x_{i}, \gamma\right)+\varepsilon_{i}
$$

In non linear regression models, the number of regression parameters is not directly correlated with the number of explanatory variables therein. The $\gamma$ in equation 2 is the non-correlated error term for the unknown parameters in the form of $n \mathrm{p} \times 1$ vector, $\varepsilon, \mathrm{E}(\mathrm{e})=0$ and $\operatorname{Var}(\mathrm{e})=\sigma 2 ; \mathrm{f}\left(\mathrm{x}_{\mathrm{i}}, \gamma\right)$, on the other hand, is described as the expectation function for the non linear regression model (Ratkow sky, 1983).

\section{Cobb-Douglas Hybrid Modeling}

Regression method is more commonly found in the product market than nonlinear mathematical models. The Cobb-Douglas hybrid modeling has been developed based on the linear and non-linear models in the appraisal of real estate values. This model is called the hybrid model as it incorporates the elements from both linear and non-linear models. Since this model can be used in the appraisal of real estates with or without a building, it allows one to identify the value of the land in the absence of a building. As shown in the example below, the first part of the model -the one with the A variable- 
demonstrates the land characteristics, while the other part -the one with the $\mathrm{Y}$ variable- reveals the building characteristics.

$$
P i=\beta_{0} A_{1, i} \beta_{1} A_{2, i} \beta^{2} A_{3, i} \beta 3 \ldots+\theta_{0} Y_{1, i} \theta_{1} Y_{2, i}{ }^{\theta} Y_{3, i}{ }^{\theta 3} \ldots .
$$

$A_{j, i}:$ Land characteristics (the study includes a total of 17 variables) (17 criteria in the study)

$Y_{j, i}:$ Building characteristics (the study includes a total of 6 variables) (6 criteria in the study)

$\mathrm{B}_{0,(\mathrm{i}-1)}$ and $\theta_{0,(\mathrm{i}-1)}$ denote the fixed parameters pertaining to the land and building (McCain et all, 2003; Rossini and Kershaw, 2005).

\section{APPLICATION}

\section{Study Area}

It comprises the urban renewal area that is being developed around Uluirmak Distrcit and its vicinity in Meram county, Konya province. According to the data obtained from the Urban Renewal Department of Meram Municipality, the study area contains a total of 1078 real estates, 372 of which have no buildings on them (land) and 706 have construction on them. A total of 23 criteria have been established with respect to the said real estates, 17 of which are concerning to the land and 6 to the buildings and facilities erected on them. The real estates with construction include domiciles with and without garden, detached properties, apartment blocks, reinforced concrete buildings, adobe houses and w arehouses. In terms of ow nership, how ever, 666 of them belong to private persons, 2 to associations, 1 to public, 2 to Konya Metropolitan Municipality, 15 to Meram Municipality, 8 to corporations and 8 to foundations. While the total surface area of the project is $266.843 \mathrm{~m}^{2}$, the cadastre project area, including current derelicts areas, is $232.990 \mathrm{~m}^{2}$. The project was allocated an area of $20.760 \mathrm{~m}^{2}$ for developing schools, squares, social facilities, green areas, car parks etc. The illustrative value set in the project for the urban renewal site is 1,80 rate. The implementation plan for the area is presented in Figure 1.

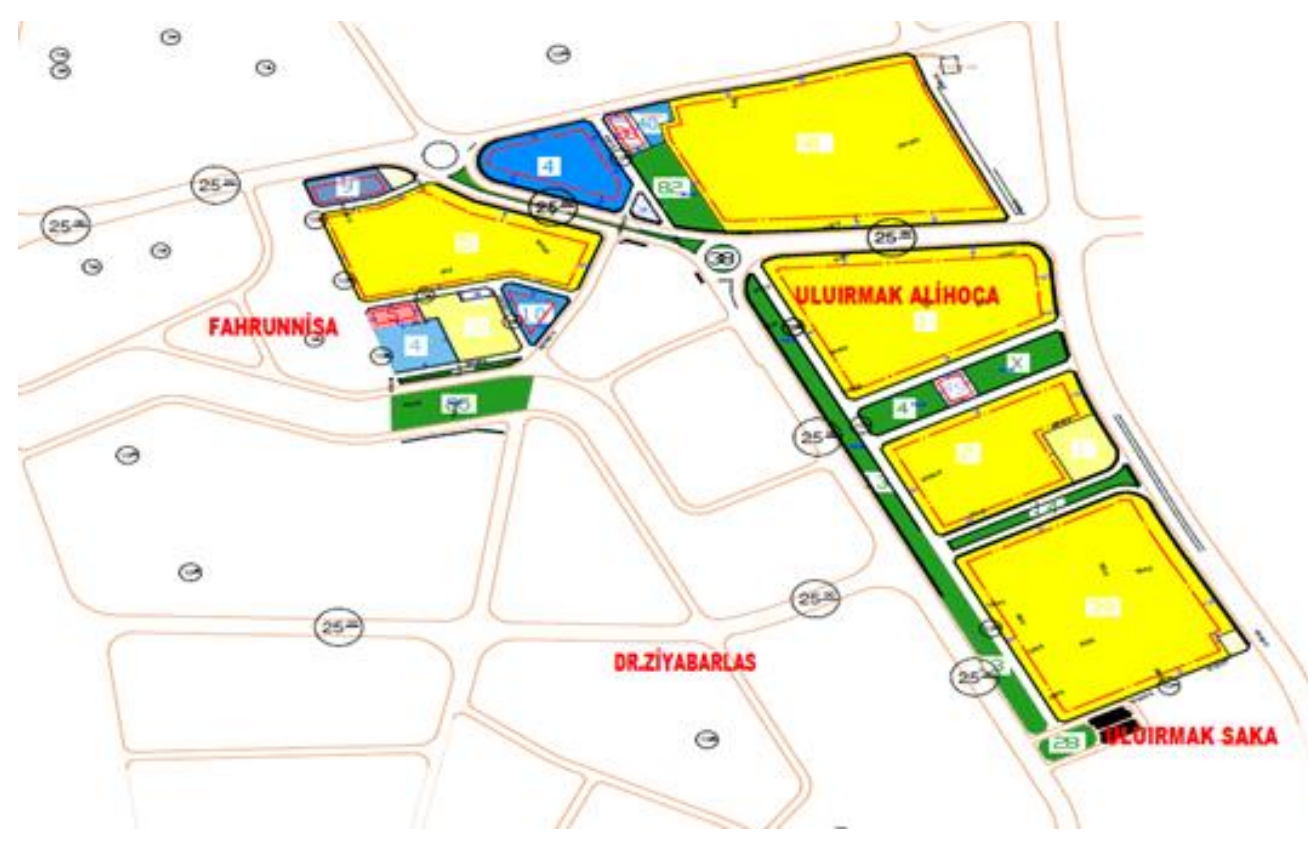

Figure 1. The map of implementation plan for Uluirmak area 


\section{Quantification of the data and normalization procedure}

The data set obtained from Meram Municipality is arranged in the form of columns allocated to lands and buildings by using Excel. Since the data we had composed of both digital and verbal contents, a scoring procedure was conducted to convert the verbal data into the digital form. The study conducted by Yomralioglu (1997) was used while scoring each criterion separately in itself. Scoring procedure was conducted solely for the purposes of converting the verbal data into the digital one. The digital values contained in the data set were maintained.

Due to the differences observed between the units and value gaps in each criterion, it became necessary to conduct a normalization procedure following the arrangement of the data set. A normalization procedure was conducted for the values contained in each criterion within the value gap ranging from min to max. The Equation $4 \mathrm{w}$ as employed for the said criteria by setting the maximum value at 2 and minimum value at 1 .

$$
\text { Xnorm }=(\mathrm{Xi}-\mathrm{Xmin}) /(\mathrm{Xmax}-\mathrm{Xmin})+1
$$

\section{RESULTS}

The nonlinear regression model (Equation 3) was applied to the arranged and normalized data set by using the SPSS 15 software package, as a result of which the values of the fixed variables were found as presented in the Table 1. The conformity of the mathematical model thus created was tested with the aforementioned software package. To this end, 23 criteria found through the normalization procedure and the values of 1078 real estates, as of 2015, were input to the program and the relationship between the data $w$ as studied in the program using a correlation method.

Of such coefficients, the ones specified as ' $\beta$ ' were concerned with the characteristics associated with lands, while the ones specified as ' $\theta$ ' were concerned with the characteristics associated with buildings. It $w$ as established that the criteria that affected the value of the land the most were $\beta_{12}$ (Allotment area), $\beta_{17}$ (Partnership arrangement to share the flooded areas) and $\beta_{11}$ (Parcel multiplier coefficient), while the ones that affected it the least were $\beta_{4}$ (Construction license status) and $\beta_{5}$ (Area of use license status). As for the characteristics associated with buildings, the criteria that affected the value the most were $\theta_{1}$ (The gross building area) and $\theta_{6}$ (Floors condition of real estate), the one that affected the least was $\theta_{3}$ (Outbuildings area) type. While the criteria of $\theta_{4}$ (Garden wall length) and $\theta_{5}$ (Number of trees) had an equal effect on the value (Table 1 ).

According to this model, the number of characteristics associated with the buildings and other inventories erected on the land are more than the effects of the criteria associated with the land. The Cobb-Douglas Hybrid regression model established for the purposes of this study was found to be highly successful. The results of the model are presented in the Table 2.

According to the Table 2; $\mathrm{R}^{2}=1$-(Residual Sum of Squares)/ (Corrected Sum of Squares) =0,941. By applying the model created through the coefficients obtained from the SPSS program to the data set, we have identified the model values for the real estates covered within the scope of the urban renewal study. Following the modeling obtained through the real estates in the data set, (estimated values) were compared. As a result of this comparison, the absolute error was found as $2,05 \%$. 
Table 1. Cobb-Douglas Hybrid regression coefficients

\begin{tabular}{|l|cc|l|cc|}
\hline \multicolumn{1}{|c|}{ Criteria } & $\begin{array}{c}\text { Parameters } \\
\text { of the } \\
\text { criteria }\end{array}$ & $\begin{array}{c}\text { Estimate } \\
\text { Lower } \\
\text { Bound }\end{array}$ & \multicolumn{1}{|c|}{ Criteria } & $\begin{array}{c}\text { Parameters } \\
\text { of criteria }\end{array}$ & $\begin{array}{c}\text { Estimate } \\
\text { Lower } \\
\text { Bound }\end{array}$ \\
\hline Constant & $\beta_{0}$ & 0,320 & Total abandonment & $\beta_{13}$ & 0,070 \\
Location & $\beta_{1}$ & $-0,270$ & Total area of parcels & $\beta_{14}$ & $-0,158$ \\
Parcel type & $\beta_{2}$ & $-0,045$ & Excluding commercial space & $\beta_{15}$ & $-0,073$ \\
Land status & $\beta_{3}$ & $-0,185$ & Share falling area & $\beta_{16}$ & $-0,041$ \\
Construction license & $\beta_{4}$ & $-0,025$ & Partnership arrangement to \\
status & $\beta_{5}$ & $-0,029$ & Constant & $\beta_{17}$ & 0,772 \\
Area of use license status & $\beta_{6}$ & 0,163 & The gross building area & $\theta_{0}$ & 0,660 \\
Causing to settle in & $\beta_{7}$ & 0,233 & Common area of use & $\theta_{1}$ & 0,306 \\
Marketing authorization & $\beta_{8}$ & $-0,046$ & Outbuildings of area & $\theta_{2}$ & 0,124 \\
Type of soil & $\beta_{9}$ & $-0,737$ & Garden wall length & $\theta_{3}$ & 0,020 \\
Independent part total & $\beta_{10}$ & $-0,254$ & Number of trees & $\theta_{4}$ & 0,052 \\
Independent part quality & $\beta_{11}$ & 0,767 & Floors condition of real & $\theta_{5}$ & 0,052 \\
Parcel multiplier factor & $\beta_{12}$ & 1,515 & & $\theta_{6}$ & 0,229 \\
Allotment area & & & & \\
\hline
\end{tabular}

Table 2. Results obtained for the Cobb-Douglas Hybrid model

\begin{tabular}{|l|rcr|}
\hline Source & $\begin{array}{r}\text { Sum of } \\
\text { Squares }\end{array}$ & df & $\begin{array}{c}\text { Mean } \\
\text { Squares }\end{array}$ \\
\hline Regression & 1447,221 & 25 & 57,889 \\
Residual & 1,090 & 1052 & 0,001 \\
Uncorrected Total & 1448,311 & 1077 & \\
Corrected Total & 18,392 & 1076 & \\
\hline
\end{tabular}

The $\mathrm{R}^{2}$ and linear equations obtained as per the trend line which was established based on the real estate values found through the nonlinear regression model as well as the distribution and scattering of the values in the data set- were studied (Figure 2). The proximity of the $\underline{\mathrm{R}^{2}}$ point distributions obtained as a result of the graphical distribution- to the line is that of the specified value. Success increases as it comes near the point 1 . If the model results are found to be $100 \%$ and as the line will be established as $y=x$ in the equation, the success of the study will increase when the coefficient of $x$ is 1 or thereabouts. The fact that, as a result of the study, the $\mathrm{R}^{2}$ and equation have been established as 0,9986 and $y=0,9369 x$ respectively suggests that Cobb-Douglas Hybrid model is a successful and usable model for value estimations as shown in the case of the present urban renewal study.

\section{CONCLUSIONS}

Performance of sample urban renewal matching based on only the area related criteria in the previous urban renewal studies resulted in a number of unjust and unfair implementations. That approach led to financial grievances on the part of the citizens and devaluation of the properties by losing sight of the characteristics that actually affect the value of real estate. In order to eliminate such injustice, it is essential that the legal and physical characteristics of each real estate are determined and the valuation is done based on such characteristics and that the calculated value is matched with real estate to present after urban renewal project. For this reason, the urban renewal area located at Uluirmak District in Meram/Konya county was calculated in terms of real estate values using CobbDouglas Hybrid model and the success of the mentioned model was examined. As a result of the study, the model was found to be highly successful at the point of accurate value estimation. 


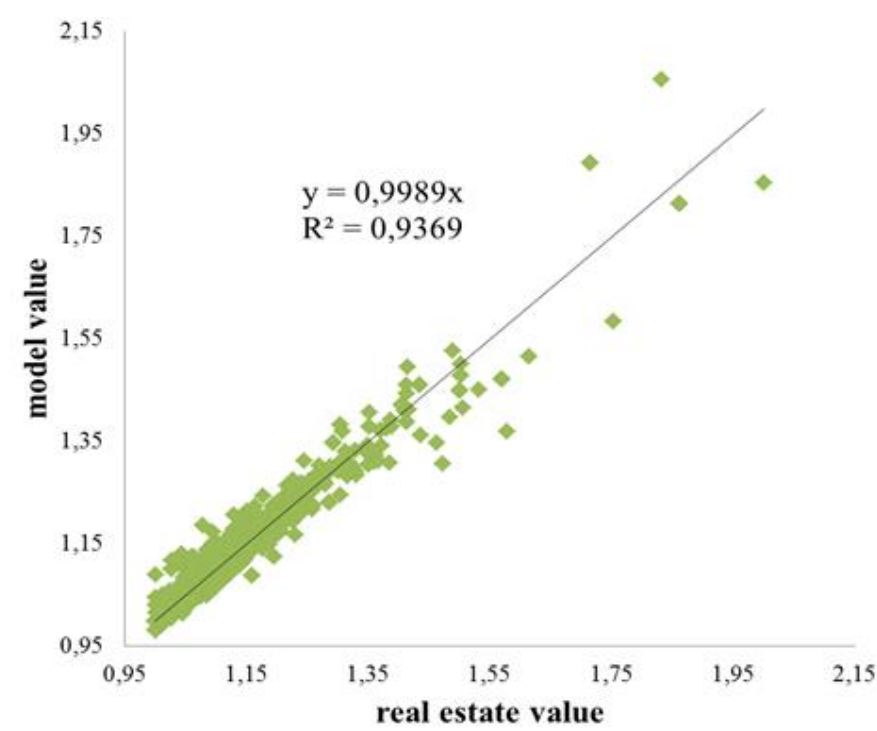

Figure 2. Comparing Cobb-Douglas Hybrid model with model and market values

Time is of the essence in urban renewal projects. It becomes more and more difficult and time consuming to appraise the value of the real estates as the number of characteristics associated with them increase. For this reason, increasing the number of criteria is no longer a preferred method in value appraisal. The model developed in this study is highly beneficial in terms of time and cost saving. By using this method, it is anticipated that the real values of real estates can be established in a short space of time and an equal valuation. So it can be maintained through fixed points of the criteria that apply to everybody. This way, the more characteristics of real estate has the more accurate and easier to determine its value. Through this study, unobjective real estate valuation will be avoided, and the one sided view and opinion of the real estate appraiser will be eliminated.

Moreover, the fact that the land and buildings are available at the same time will not make any difference in the model in terms of establishing the values of the land and the buildings and other inventories thereon on a separate basis nor will it require a remodeling. The model will be able to use in both circumstances. The model thus created will also be efficient in terms of identifying the criteria that are not compulsory to be addressed.

\section{ACKNOWLEDGEMENT}

We appreciate the support of Meram Municipality for this study. This publication was presented as oral presentation in ISCAS-2016 Antalya/TURKEY.

\section{REFERENCES}

Alpar, R., 1997, Uygulamalı Çok Değişkenli İstatiksel Yöntemlere Giriş-1, Kültür Ofset, Ankara.

Din, A., Martin H., Andre B., 2001, “Environmental Variables and Real Estate Prices", Urban Studies, Vol. 38(11), pp. 1989-2000.

Isakson, H. R. 2001, “Using Multiple Regression Analysis in Real Estate Appraisal Excerpt from Papers and Proceedings", Appraisal Journal, Vol. 69(4), pp 424-430.

Kutner M. H., Neter J., Nachtsheim C.J., Wasserman W., 1996, Applied Linear Statistical Models, McGraw Hill.

McCain, R. A., Jensen, P., Meyer, S., 2003, Research on Valuation of Land and Improvements in Philadelphia, Department of Economics and International Business, LeBow College of Business Administration, Drexel University, Philadelphia, 1-24. 
Orhunbilge, N., 2002, Applied Regression and Correlation Analysis, Istanbul University Publication, Istanbul, ISBN, 975-404.

Ozkan, G., Yalpir S., “Taşınmaza Ekonomik Bakış ve Değerlendirmesi”, 10. Türkiye Harita Bilimsel ve Teknik Kurultayı, Ankara, 28 Mart - 1 Nisan 2005.

Ratkowsky, D. A., 1983, Nonlinear Regression Analysis, Marcel Decker Inc., New York.

Rossini, P., Kershaw, P., 2005, “Using a Hybrid Automated Valuation Model to Estimate Capital and Site Values" (Doctoral dissertation, Pacific Rim Real Estate Society (online)).

Rossini, P., 1998, “Improving the Results of Artificial Neural Network Models for Residential Valuation", Fourth Annual Pacific-Rim Real Estate Society Conference, Perth, Western Australia, 19-21 January 1998.

Stephen M., Lennon C., Winky H., 2010, “Quantile Regression Estimates of Hong Kong Real Estate Prices", Urban Studies, Vol.47(11), pp. 2461-2472.

Ucar, C., 2009, Kentsel Dönüşümün Uygulama Bölgesi Dinamiklerine ve Taşınmaz Değerine Etkileri, Master Thesis, Institute of Science and Technology, ITU University, Istanbul.

Yalpir, S., Ozkan, G., Erdi, A., 2002, “Kentsel Alanlarda Taşınmaz Değerlerinin Belirlenmesi ve Konya Örneği", Selçuk Üniversitesi Jeodezi ve Fotogrametri Mühendisliği 30. Yıl Sempozyumu, Konya, 1618 Ekim 2002.

Yomralioglu, T., 1997, Kentsel Alan Düzenlemelerinde Imar Planı Uygulama Teknikleri, Jeodezi ve Fotogrametri Derneği (JEFOD) Yayın no:1, Trabzon. 